\title{
Seismicity and seismotectonics of the Jeddah area, Saudi Arabia
}

\author{
M. S. Fnais ${ }^{1}$, K. Abdelrahman ${ }^{1,2}$, Sh. E-Hady ${ }^{2}$ \\ \& E. Abdel-monem ${ }^{2}$ \\ ${ }^{1}$ Geology and Geophysics Department, College of Science, \\ King Saud University, Riyadh, Saudi Arabia \\ ${ }^{2}$ Seismology Department, National Research Institute of Astronomy and \\ Geophysics, Cairo, Egypt
}

\begin{abstract}
The Jeddah area is located along the eastern coast of the Red Sea and hence has been affected by moderate to destructive earthquakes throughout its history. Consequently, the identification of the seismogenic source zones is of utmost importance for mapping the most disaster prone area around the Jeddah area. Available data, including both historical and instrumental have been collected from national and international data centers. The seismogenic source zones that might affect the Jeddah area are defined more precisely depending on the main tectonic trends; distribution of earthquakes, seismicity rate (a- and b-values) and a fault plane solution for the major earthquakes; in addition, the type of faults that prevail and characterize these zones. It is concluded that Jeddah city is outlined by five seismogenic source zones; three of them are located through the Red Sea (southwestern Jeddah, western Jeddah, and northwestern Jeddah), while the other two earthquake zones are located inland (Thewal-Rabegh and JeddahMakkah zones). The existence of microearthquakes inland suggests that there is a significant level of tectonic activity away from the axial trough of the Red Sea. These inland zones correlate well with the major active tectonic trends outlining the Jeddah area. The b-values range from 0.65 to 1.03 through the study area. An area of high b-values could be indicative of a relative low stress regime resulting from the stress release by the earthquakes. An area of low bvalues is interpreted as evidence of a relatively higher stress regime associated with an area of dominantly extensional stress. Due to this complicated tectonic setting and stress heterogeneities for the Jeddah area, detailed earthquake
\end{abstract}


monitoring is highly recommended. These results are valuable for seismic hazard assessment of the Jeddah area for anti-earthquake structures of the developmental and urbanization projects.

\section{Introduction}

The Jeddah area is located in the west-central part of Saudi Arabia along the eastern coast of the Red Sea (Fig. 1). Jeddah city is the second major city through Saudi Arabia where; 1) it has one of the famous harbors along the Red Sea coast; 2) it has most of strategic industries, multi-national commercial companies and developmental projects; 3 ) it has a great number of population of about 2.5 million of national citizens and residents and 4) it receives millions of Muslims for the annual pilgrimage, the Hajj, at Makkah Al-Mukarramah (about $80 \mathrm{~km}$ east of Jeddah city) and throughout the year for the lesser pilgrimage the Umrah. Furthermore, Jeddah area was experienced some of destructive earthquakes in recent and historical. The maximum recorded earthquake had a 7.2 magnitude in 1967 to the southwestern side of Jeddah city in the Red Sea axial trough. This earthquake affected Jeddah and adjacent area.

Accordingly and due to the abovementioned, it is very important to evaluate the earthquake activity and its relation to the tectonic trends through the Jeddah area. These data will represent the input parameters for the seismic hazard assessment study of the area.

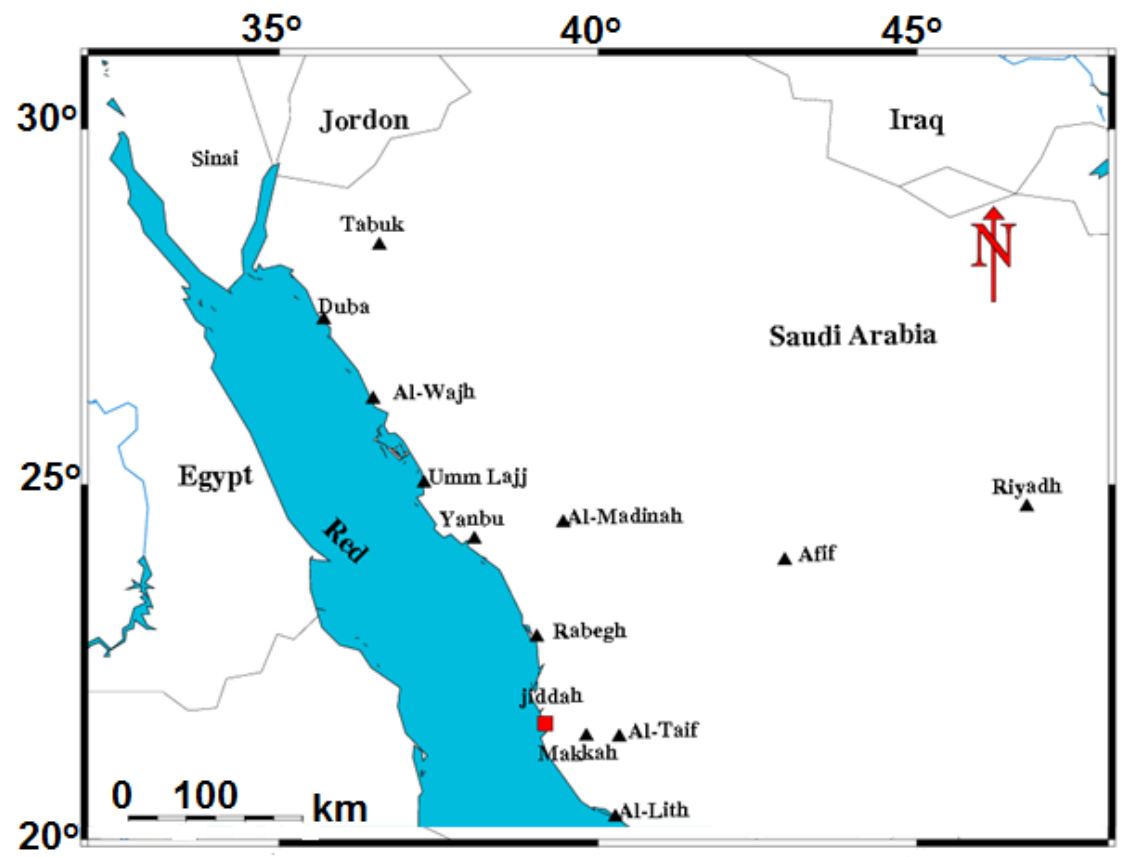

Figure 1: $\quad$ Location map for the Jeddah area. 


\section{Geological setting}

The Jeddah area is constituted by alluvial sand, sabkha soil and coralline reef rocks while the hills and mountains east of Jeddah consist of metamorphosed rocks and intrusive batholiths (Greenwood et al. [12]; Skiba et al. [22]; Moore and Al-Rehaili [15]). These units vary greatly in their thickness, topographic setting and physical properties. The region has high topographic features resulted from the uplifting associated with Red Sea rifting. The elevations vary mainly between 300 and 980 meters above sea level. In the middle of the mapped area elevation increases and the topography tends to be rugged and high massive mountains of weakly deformed and slightly weathered rocks dominate. In addition, there are subordinate sedimentary rocks and basaltic lava flow of Tertiary and Quaternary age (Sonbul [23]).

Cenozoic rocks inland from Jeddah crop out in basins that have faulted and (or) depositional contacts. They occur on a south-southeast trend from Khulays, separated from the main part of the Red Sea basin in the vicinity of Jeddah by a horst of Precambrian basement. Smaller basins farther south are effectively embayments of the main Red Sea basin. Dips within the basins are mostly to the east. A dissected horizontal sheet of basalt belonging to Harrat Rahat extends over the basins and surrounding Precambrian south of Khulays indicating that basin formation and eastward tilting of the sedimentary rocks occurred prior to basalt extrusion (i.e. prior to about $5 \mathrm{Ma}$ ).

The coralline limestone contains cavities filled with alluvial sand, shell fragments or marly material (Al-Solami et al. [7]). The alluvial sand constituted by brown silty sand. This alluvial sand covers major soil unit in Jeddah. This sand is extends also to the eastern part of the coralline limestone and locally underlies it or interfingers with it in the subsurface. Sometimes, clay and gravel lenses are embedded in the silty sand unit. While, the terraced sands are presented in the alluvial fans where the main wades flowing from the east and discharge into the alluvial plain. This unit consists of gravel, sand, and small percentage of fines. The sabkha soil is located in small depressions near the coastline in the low relief areas or in depressions within the coralline limestone. They are mainly of silty nature with seems and pockets of cohesive soils. These soils grade in color from dark gray to brownish gray and becoming grayish white in some locations.

The Saudi Arabian Red Sea coastal plain occupies the northeastern part of the $\mathrm{NW}$-oriented Red Sea rift that was formed as a result of the divergence between the African and Arabian plates since the Oligo-Miocene time. The continental crust of the northern Red Sea is composed mainly of $140-150^{\circ}$ (Clysmic) striking fault blocks truncated by transverse features (Cochran and Martinez, 1988).The Red Sea rift is traditionally referred as the "Clysmic" rift, after the ancient Roman name of the Red Sea as the sea of Clysma. This rift initiated in the Oligo-Miocene time. The sedimentary cover of the coastal plain ranges in age from Tertiary to Quaternary and rests nonconformably on Precambrian igneous and metamorphic rocks of the Arabian-Nubian Shield. It can be divided 
into a pre-rift (Pre-Oligo-Miocene) sequence overlain, with a major angular unconformity, by a syn-rift (Oligo-Miocene to Quaternary) succession. The structural architecture of the Red Sea coastal plain has been discussed in the works of Montenat et al. [16]; Philobbos et al. [18]; Purser et al. [20]; Abd ElMotaal [1]; Purser and Philobbos [19]; Moustafa [17] and Khalil et al. [13].

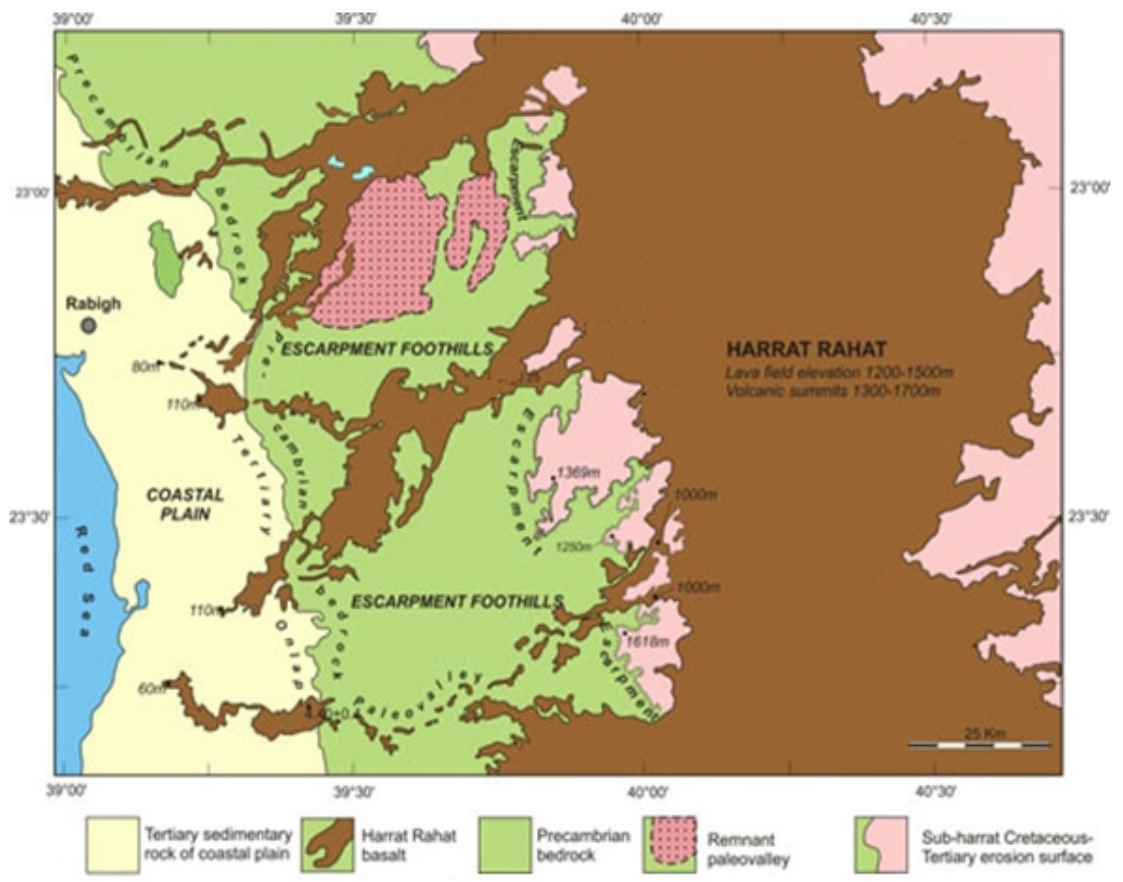

Figure 2: $\quad$ Main geological units through the Jeddah area.

Different tectonic trends are clearly identified through the area (Fig. 3) as follows; 1) N-S; 2) NE-SW fault trends occupying an area of approximately $600 \mathrm{~km}$ along the Red Sea coast, extending from Al-Lith to Yanbu and $150 \mathrm{~km}$ inland, the trend of these lineaments as well as the lithostratigraphic belts attain a NE direction. There are three major faults (e.g. Ad Damm and Wadi Fatima faults to the south of Jeddah and Bir Um Buq fault to the north) are well documented in the area. These structural trends reflect the major phases of Precambrian deformation and Tertiary faulting.

\section{Earthquakes data}

The earthquake catalogue for the Jeddah area has been collected through different sources, i.e., Saudi Geological Survey (SGS); Seismic Studies Center 


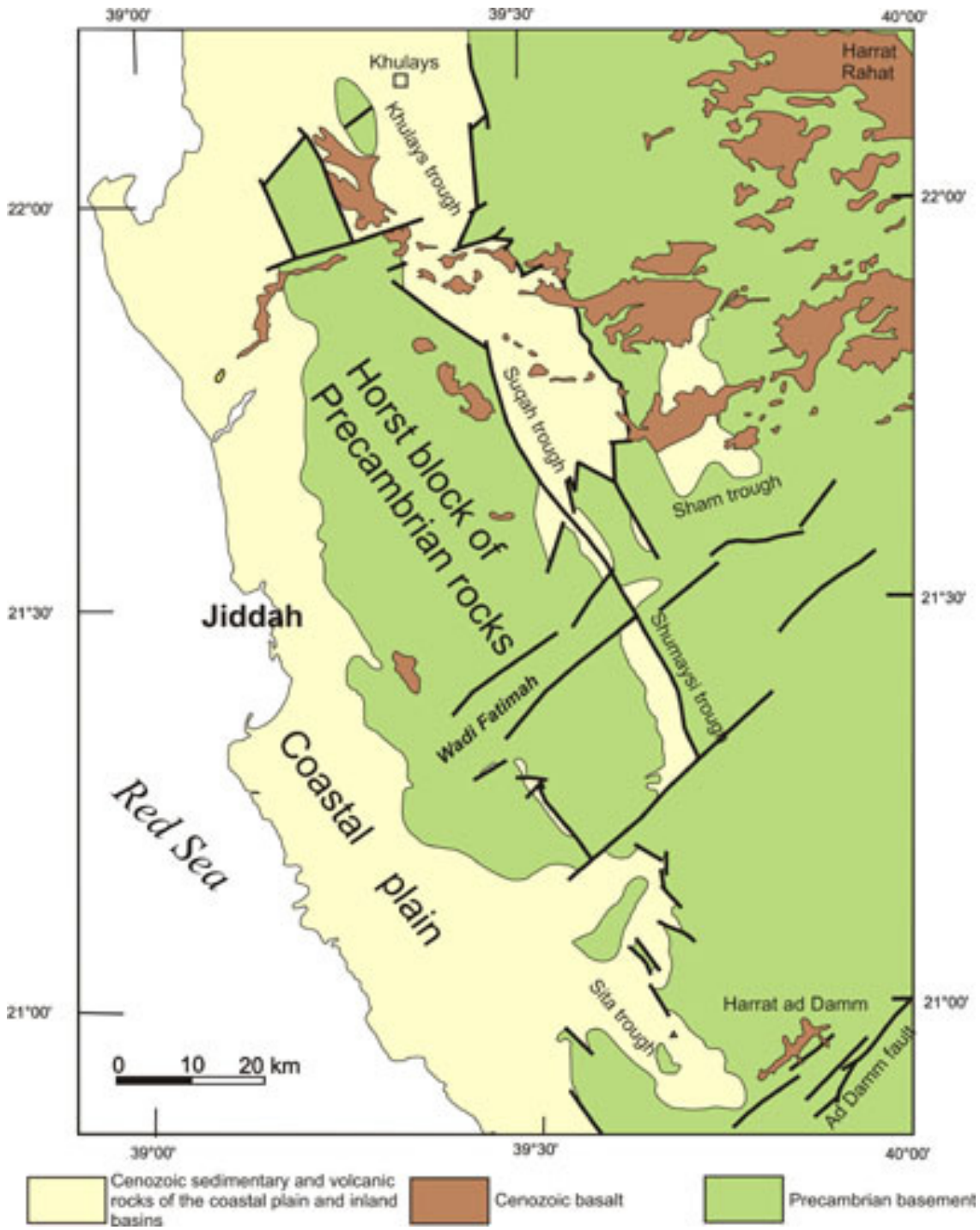

Figure 3: $\quad$ Inland affecting structures of the Jeddah area.

(SSC) of King Saud University and King Abdul-Aziz City of Science and Technology (KACST). Furthermore, microearthquake activity around the Jeddah area (Merghelani and Gallanthine [14]) is also included. These data are merged, precisely reviewed, re-analyzed and refined from duplicated events through the International Seismological Center (ISC); United States Geological Survey (USGS); and the European Mediterranean Seismological Center (EMSC). Scordilis [21] relation has been used to unify different magnitude scales into moment magnitude. Finally, spatial distribution of the compiled seismicity 
catalogue is plotted into seismicity maps for the Jeddah area (Figs. 4-6). In addition, foreshock and aftershock sequences have been omitted from the catalogue using the windowing procedure proposed by Gardner and Knopoff [11].

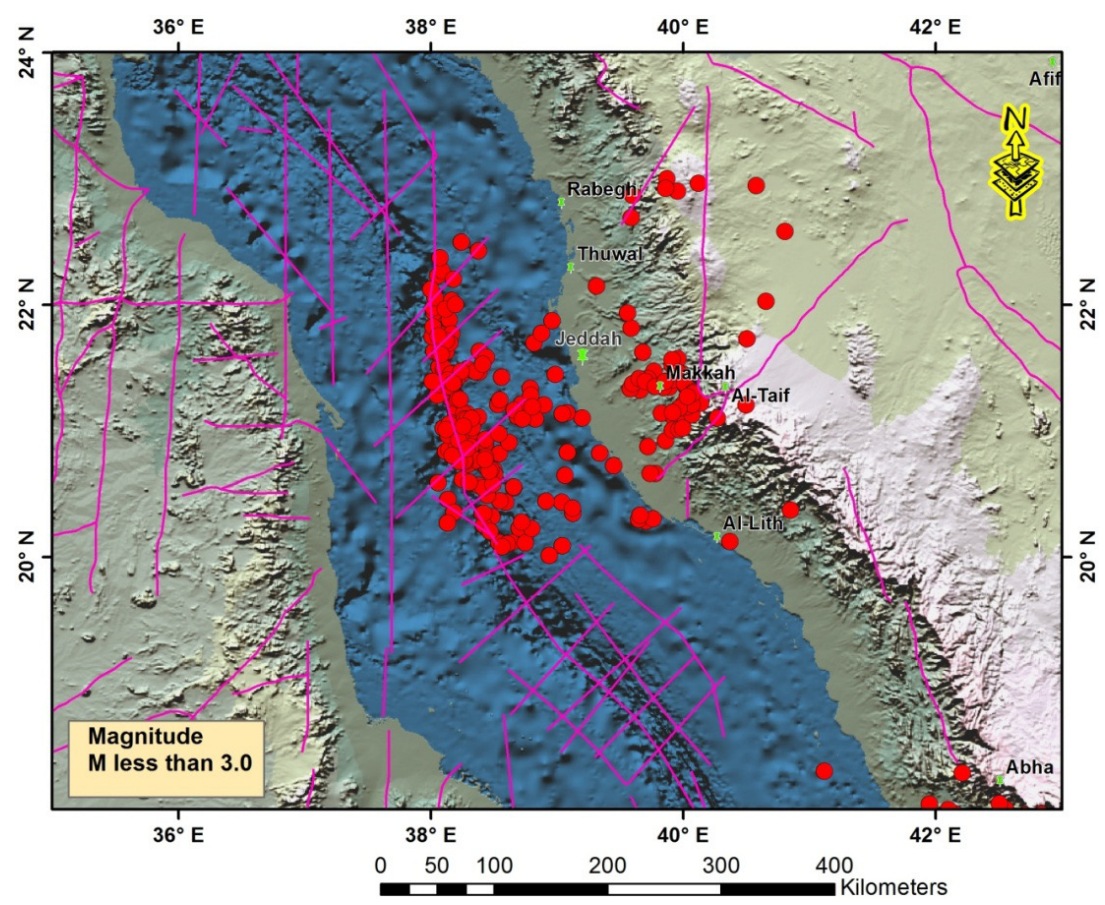

Figure 4: Distribution of earthquakes with magnitude $<3.0$ through the Jeddah region.

\section{Seismotectonic zones}

Depending on the distribution of earthquakes, fault parameters (strike and dip) of the major structural trend, seismicity parameters (a- and b-values, Table 1) and previous geological and geophysical studies (Alwash and Zakir [4]; Al-Qarni [5]; Al-Garni et al. [3]; Al-Garni and El-Kaliouby [2]), five seismogenic source zones have been identified (Fig. 7). Three zones located the Red Sea axial trough (northwestern Jeddah, western Jeddah and southwestern Jeddah zones), while the other two zones located inland (Thuwal-Rebegh and Jeddah-Makkah zones). 


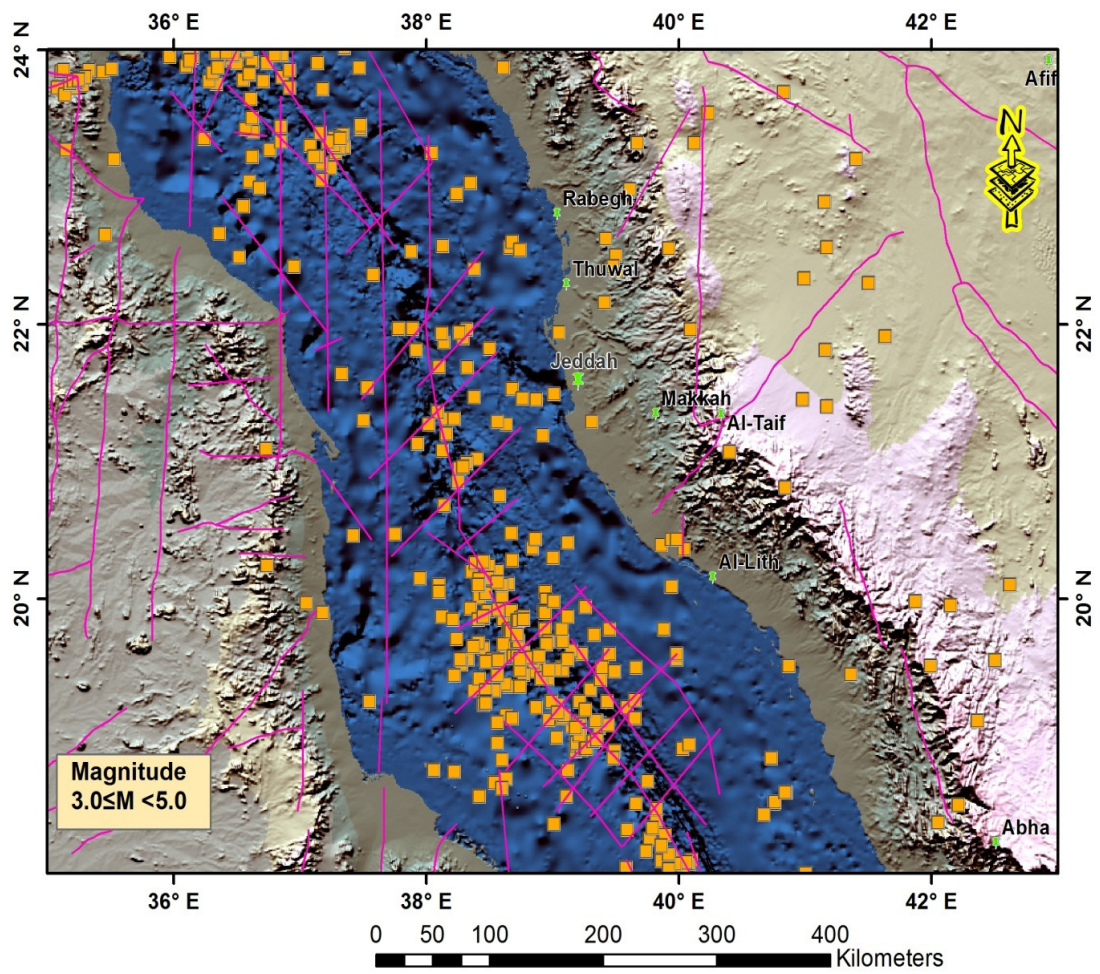

Figure 5: Distribution of earthquakes with magnitude range $3.0 \leq \mathrm{M}<5.0$ through the Jeddah region.

Table 1: $\quad$ Seismicity parameters for the identified source zones.

\begin{tabular}{|lccc|}
\hline \multicolumn{1}{r}{ Zone Name } & $\mathrm{a}$ & $\mathrm{b}$ & $\mathrm{M}_{\max }$ (observed) \\
\hline Northwestern Jeddah & 2.31 & 0.71 & 4.5 \\
& & & 5.4 \\
\hline Western Jeddah & 2.98 & 0.77 & 7.2 \\
\hline Southwestern Jeddah & 4.42 & 0.91 & 3.8 \\
\hline Thuwal-Rabegh & 2.58 & 1.03 & 4.2 \\
\hline Jeddah-Makkah & 1.77 & 0.65 & \\
\hline
\end{tabular}




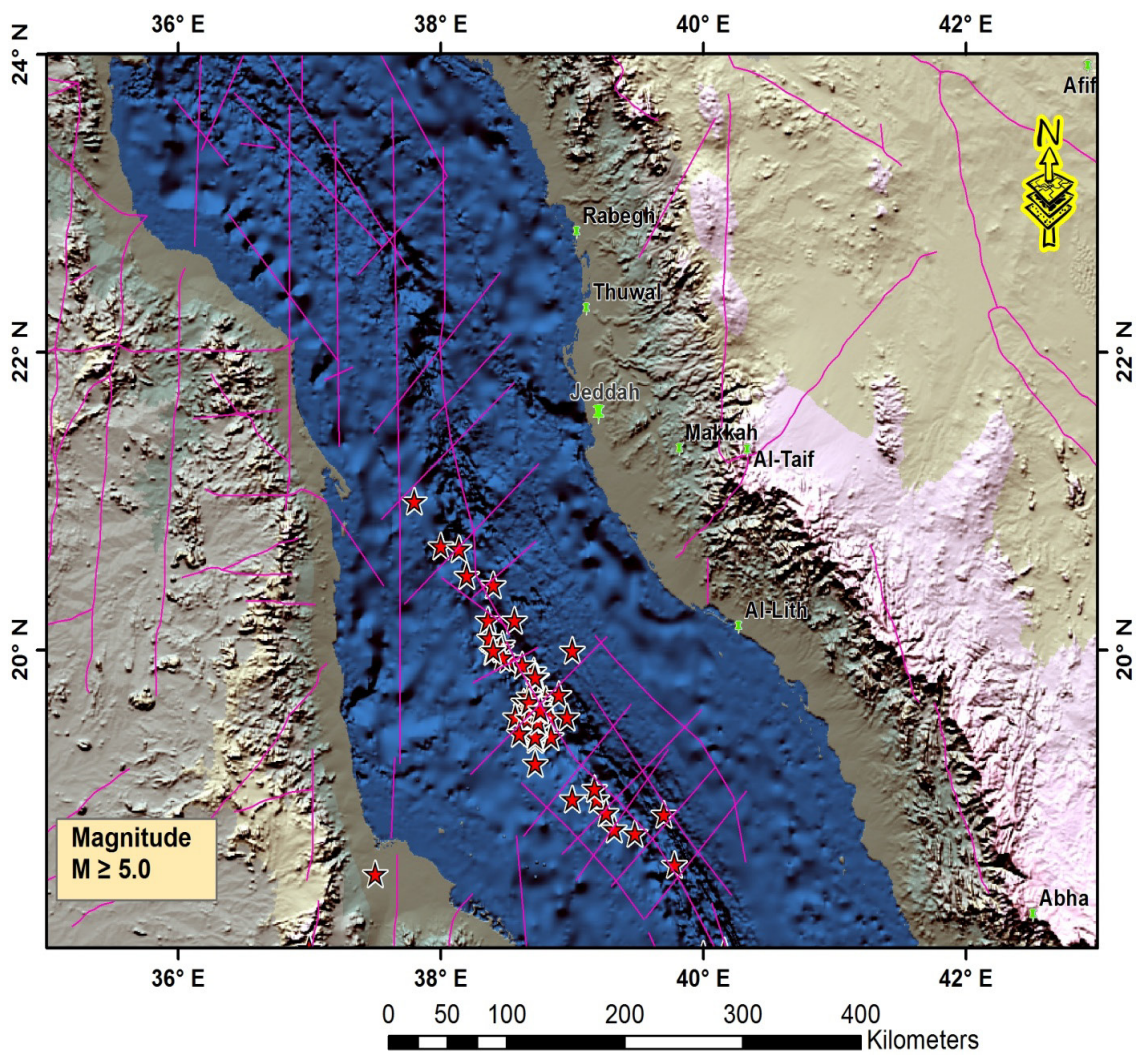

Figure 6: Distribution of earthquakes with magnitude $\leq 5.0$ through the Jeddah region.

\subsection{Jeddah-Makkah zone}

This zone includes the total area of Jeddah-Makkah and extends NE. This zone has several tectonic trends; 1) Wadi Fatima which is the major fault bounded graben with a length of about $50 \mathrm{~km}$ and a width up to $10 \mathrm{~km}$ at its southwestern end. The NE-SW major graben has an old faulting trend that is dissected by numerous NW-SE faults, related to the Red Sea tectonics (Al-Garni [5]). The presence of NNE fractures suggests the area belong to the conjugate set Tertiary fractures. The main path of Wadi Fatima extends from ENE to WSW along most of its course; however, south of Jeddah city it abruptly diverts its orientation towards the north, possibly due to active faulting (Azzedine et al. [8]); 2) AdDam active fault which is one of major fault trends through the Jeddah area.

According to $b$-value, this zone has a low b-value $(0.65)$ that can be interpreted as evidence of a relatively higher stress regime associated with an area of dominantly extensional stress (Farrell et al. [10]). 


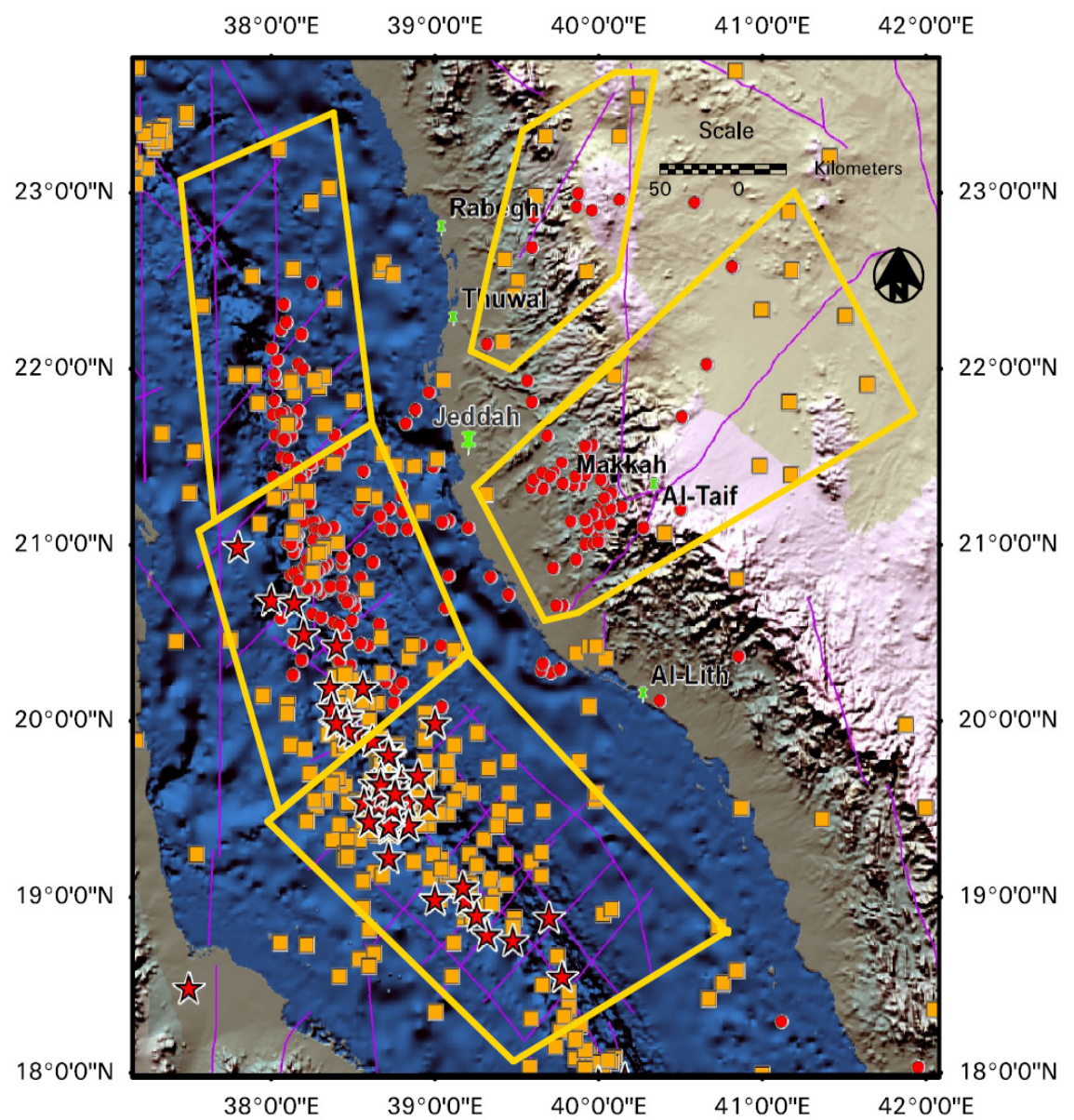

Figure 7: Seismotectonic source zones affecting the Jeddah region.

\subsection{Thuwal-Rabegh zone}

This zone covers the area to the north of Jeddah till Rabegh including Wadi Thuwal area and oriented NE to NNE. Earthquake activity in this zone (1998$2010)$ characterized by small magnitude $(\mathrm{Mw} \leq 3.8)$. This earthquake activity can be taken as indicator for tectonic activity of some recorded fault trends through this zone. The previous geological and geophysical investigations have confirmed the presence of major NE-SW and NNE-SSW fault trends through Wadi Thuwal area (Al-Garni et al. [3]; Al-Garni and El-Kaliouby [2]). In addition, evidences of shear zones are observed close to Harrat Thuwal (AlGarni and Gobashy 2009).

This zone characterized by high b-values (1.03), this could be related to the transport of magmatic fluids or could be indicative of a relative low stress regime resulting from the stress release by earthquakes (Farrell et al. [10]). 

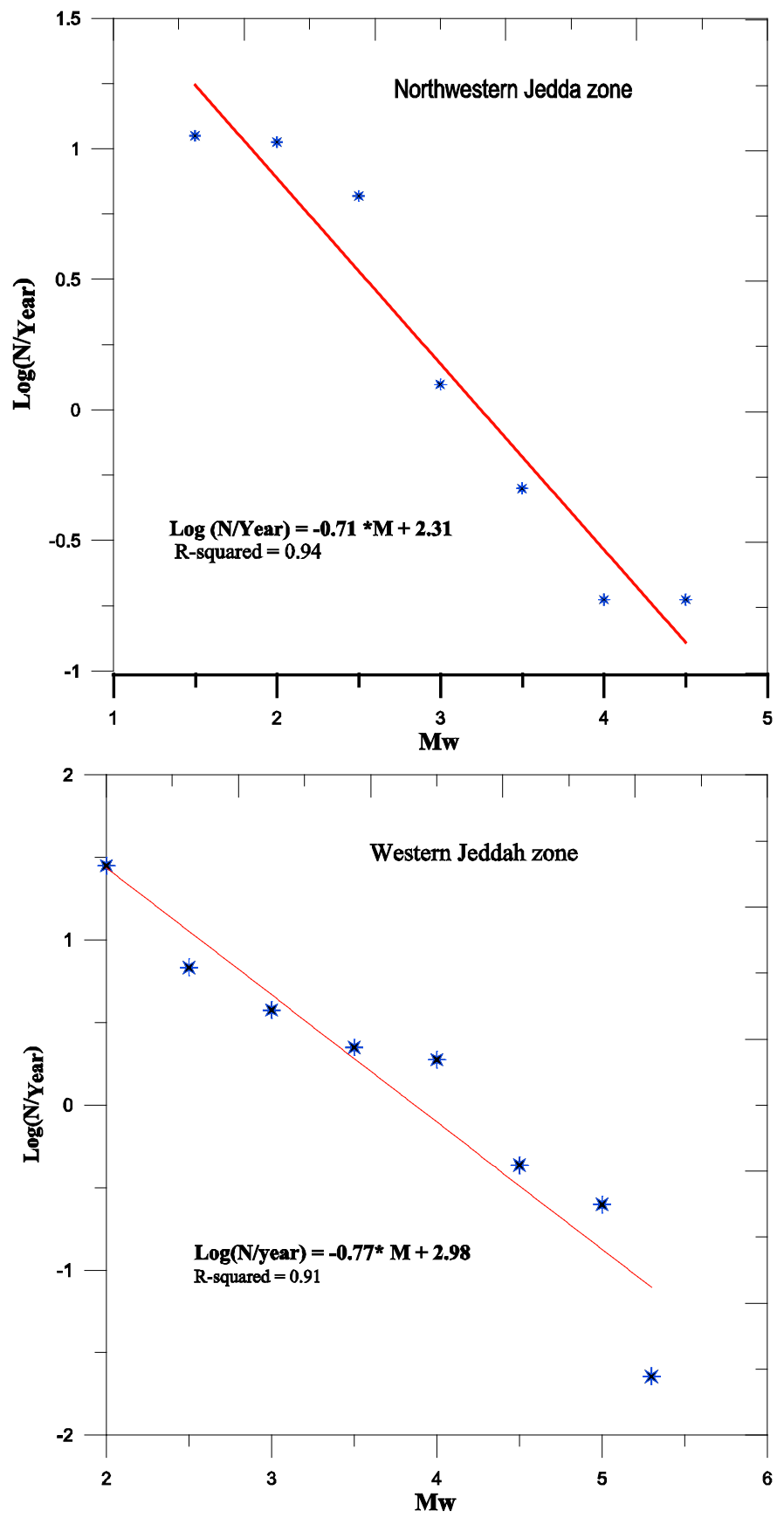

Figure 8: Seismicity parameters of the identified zones. 

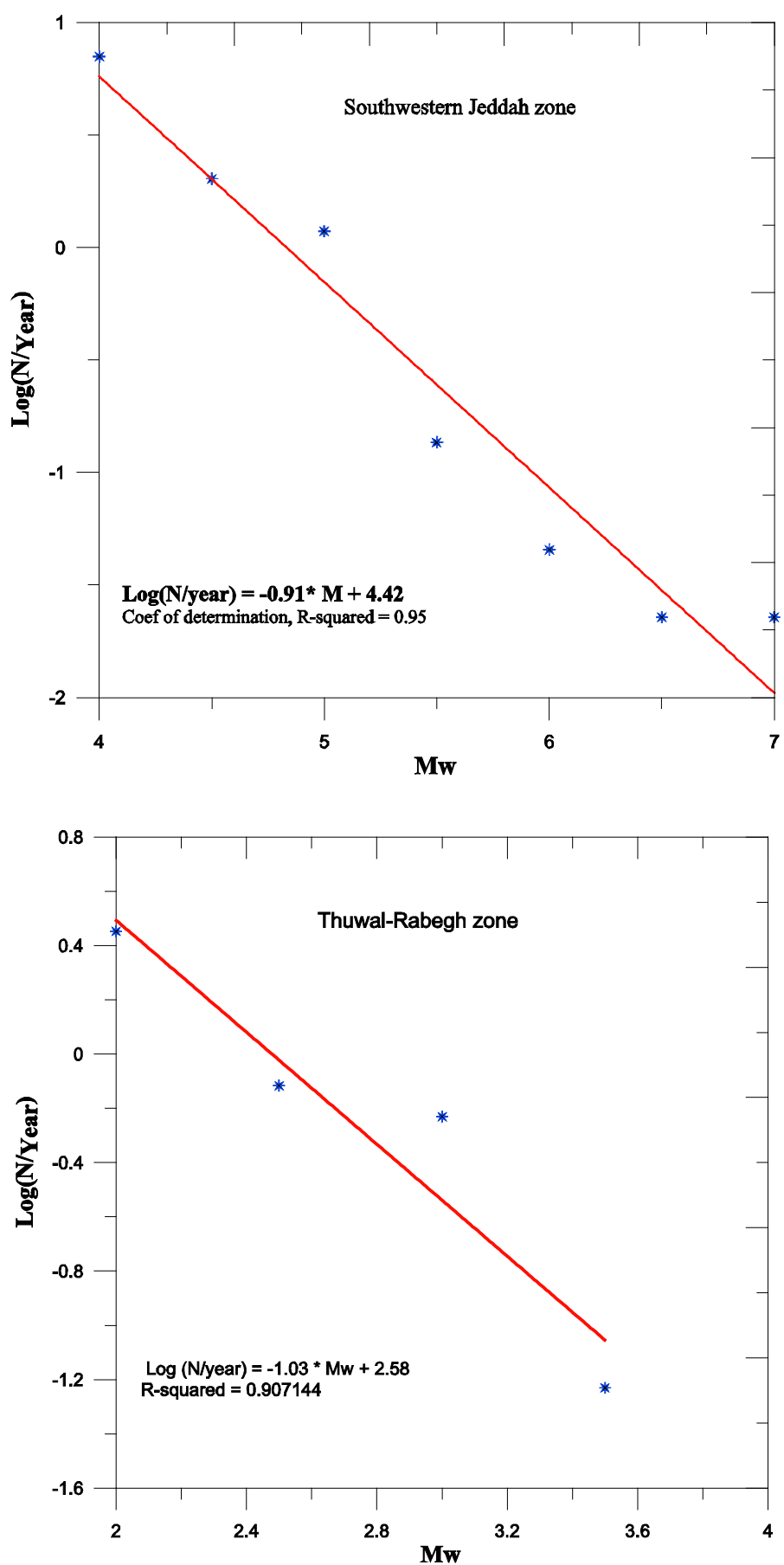

Figure 8: Continued. 


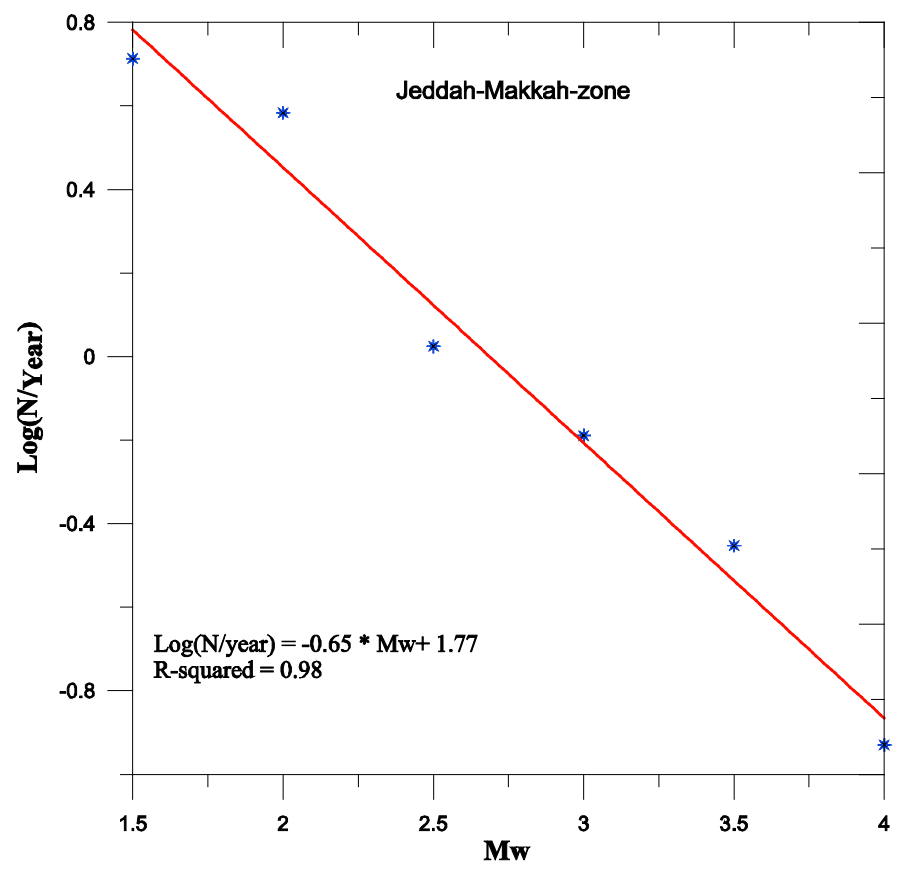

Figure 8: Continued.

\section{Conclusions}

Based on the analysis of earthquake catalogue it can be noticed that, the area has been affected by wide range of magnitudes with $\mathrm{M}_{\max } 7.2$ that occurred in 1967 . Accordingly, the earthquake data has been classified into three main categories according to their magnitudes ( $\mathrm{Mw} \leq 3.0 ; 3 \leq \mathrm{Mw}<5.0$ and $\mathrm{Mw} \geq 5.0$ ). It is noticed that all earthquakes with magnitudes greater than 5.0 have been occurred along the Red Sea main trough, while earthquakes with magnitudes less than 5.0 have recorded inland. According to earthquake epicenteral pattern, main directions of the documented faults from the geological and geophysical studies and the seismicity parameters (a- and b-value); the main seismotectonic source zones that affecting the Jeddah area have been identified as follows; northwestern Jeddah; western Jeddah; southwestern Jeddah; Thuwal-Rabegh and Jeddah-Makkah zones. The first three zones are located through the Red Sea main axial trough and characterized by greater earthquake magnitudes while; the other two are located inland and have small-moderate magnitudes.

It is noticed that both seismotectonic zones of Thuwal-Rabegh and Jeddah Makkah are very important for the area of study due to their location and recent tectonic activities. Thuwal-Rabegh zone has major NE fault trends as well as the 
presence of shear zone close to Harrat Thuwal. On the other hand, JeddahMakkah earthquake source is one of the recent earthquake prone sources, due to the presence of major tectonic fault trends of Wadi Fatima and Ad Dam and other fault trends through this zone. Owing to the great urbanization and industrial development plans of the Jeddah area, it is highly recommended that, 1) the detailed earthquake monitoring must be applied through deployment of temporary seismic network especially in the area of the active tectonic trends before new construction operations, 2) seismic hazard assessment study should be carried out for the Jeddah area for designing the anti-earthquake structures.

\section{References}

[1] Abd El-Motaal, E., 1993. Structural studies on the sedimentary rocks in the Red Sea coastal plain between lat. $25^{\circ} 45^{\prime}$ and $26^{\circ} 00^{\prime}$ N., Egypt. Ph.D. Thesis, Geol. Dept., Fac. Sci., Al-Azhar Univ., 247 pp.

[2] Al-Garni, M. and El-Kaliouby, H. 2011. Delineation of saline groundwater and sea water intrusion zones using transient electromagnetic (TEM) method, Wadi Thuwal area, Saudi Arabia. Arab J. Geosci, 4:655-668, DOI 10.1007/s12517-009-0094-5.

[3] Al-Garni, M., El-Behiry, M. and Gobash, M. 2010. Geophysical survey for geological hazards assessment of Wadi Thuwal area, KSA: a case history. Arab J. Geosci. DOI 10.1007/s12517-010-0147-9.

[4] Alwash, M. and F.A.R. Zakir, F. 1992. Tectonic analysis of the Jeddah Taif area on the basis of LANDSAT satellite data. Journal of African Earth Sciences, Vol. 15, No. 2, pp. 293-301.

[5] Al-Garni, M. 2009. Geophysical Investigations for Groundwater in a Complex Subsurface Terrain, Wadi Fatima, KSA: A Case History. Jordan Journal of Civil Engineering, Volume 3, No. 2.

[6] Alquhtani, M.B. 1998. Engineering Geology of Greater Jeddah Metropolitan. Ph.D. Thesis, Faculty of Earth Sciences, King Abdulaziz University, Saudi Arabia, 404 p.

[7] Al-Solami, A., Al Barakati, G., Shabbir A., Sayed S., Al Bahloul, S., Al Tunsi B. 2006. Engineering geological mapping of the holy city of Makkah Al Mukarramah, Saudi Arabia. IAEG2006, paper No. 552.

[8] Azzedine, B., Ritz, J. and Philip, H. 1998. Drainage diversions as evidence of propagating faults: example of the El Asnam and Thenia faults, Algeria, Terra Nova, 10: 236-244.

[9] Cochran, J.R., Martinez, F., 1988. Evidence from the northern Red Sea on the transition from continental to oceanic rifting. Tectonophysics, 153, 2554.

[10] Farrell, J., Stephan Husen, S. and Smith, R. 2009. Earthquake swarm and bvalue characterization of the Yellowstone volcano-tectonic system. Journal of Volcanology and Geothermal Research, 188, pp. 260-276.

[11] Gardner, J.K. and Knopoff, L. 1974. Is the sequence of earthquake in Southern California, with aftershocks removed, Poissonian? Bull. Seism. Soc. Am., 64: 1363-1367. 
[12] Greenwood, W.R., Hadley, D.G., Anderson, R.E., Fleck, R.J. and Schmidt, D.L. 1976. Late proterozoic cratonization in S.W. Saudi Arabia. Philosophical Transaction of the Royal Society of London, V.A 280, 3-38.

[13] Khalil, M., El-Nagdy, E., Rahman, H.A., Comisso, M., 1998. Frontier exploration in the southern Egyptian Red Sea: Superimposed Cretaceous and Tertiary rift tectonics in the newly discovered, untested Ras Benas subbasin. 14th E.G.P.C. Exploration Conf., Cairo, 1, 1-15.

[14] Merghelani, H.M. and Gallanthine, S.K. 1980: Microearthquakes in the Tihamat-Asir region of Saudi Arabia. Bulletin of the Seismological Society of America, Vol. 70, No. 6, pp. 2291-2293.

[15] Moore, T.A. and Al-Rehaili, M.H. (1989). Geologic Map Of The Makkah Quadrangle, Sheet 21D, Kingdom of Saudi Arabia, Ministry of Petroleum and Mineral Resources, Deputy Ministry For Mineral Resources Publication, Jeddah, S.A.

[16] Montenat, C., Ott d'Estevou, P., Purser, B., Burollet, P.F., Jarrige, J.J., Orszag-Sperber, F., Philobbos, E., Plaziat, J.C., Part, P., Richert, J.P., Roussel, N., Thiriet, J.P., 1988. Tectonic and sedimentary evolution of the Gulf of Suez and the northwestern Red Sea. Tectonophysics, 153, 161-177.

[17] Moustafa, A.R., 1997. Controls on the development and transfer zones: The influence of basement structures and sedimentary thickness in the Gulf of Suez and Red Sea. Jour. Structural Geology, 19, 755-768.

[18] Philobbos, E.R., El-Haddad, A.A., Mahran, T.M., 1988. Comparison between Miocene and Pliocene facies distribution related to syn-rift tectonics along the Egyptian Red Sea coastal area. E.G.P.C. 9th Petroleum and Production Conference, 1, 246-254.

[19] Purser, B.H., Philobbos, E.R., 1993. The sedimentary expression of rifting in the NW Red Sea, Egypt. Geol. Soc. Egypt, Spec. Publ., 1, 1-45.

[20] Purser, B.H., Philobbos, E.R., Soliman, M., 1990. Sedimentation and rifting in the NW parts of the Red Sea: a review. Bull. Soc. Geol. France, (8) 1, 3, 371-384.

[21] Scordilis, E.M. 2006. Empirical global relations converting $\mathrm{M}_{\mathrm{s}}$ and $\mathrm{M}_{\mathrm{b}}$ to moment magnitude. Journal of Seismology, 19, 225-236.

[22] Skiba, W.J., Tayeb, J., AI-Khatieb, S.O. Khallaf, H.M., 1977. Geology of the Jeddah-Makkah area (21/39), Kingdom of Saudi Arabia. Saudi Arabian Directorate General of Mineral Resources unpublished bulletin.

[23] Sonbul, A.R. 1995. Engineering Geology as applied to urban development of the north-western area of The Holy City of Makkah. 